\title{
ПРИНЦИПИ ВЗАЕМОДІЇ ІНСТРУМЕНТІВ В ЗМІШАНОМУ АНСАМБЛІ НА ПРИКЛАДІ ТРІО ДЛЯ СКРИПКИ, ВАЛТОРНИ ТА ФОРТЕПІАНО ОР. 40 Й. БРАМСА
}

\author{
Аспірант Ірина Смірнова \\ Сумський державний педагогічний університет імені А.С. Макаренка, Украӥна, Суми
}

DOI: https://doi.org/10.31435/rsglobal_ws/30062019/6564

\section{ARTICLE INFO}

Received: 26 April 2019

Accepted: 19 June 2019

Published: 30 June 2019

\section{KEYWORDS}

the mixed ensemble,

party,

instrument,

violin,

French horn.

\begin{abstract}
In the article the specific of co-operation of instruments is investigational in the mixed ensembles on the example of Trio of op. 40th. of Brahms. It is educed that a composer, uniting different tone quality and inequivalent from the technical and expressive points of view instruments (violin, french horn of in Es, piano) in an only ensemble, arrives at the concerted ensemble sounding due to the complex of receptions: 1) creation of thematic invention, that would answer economic and expressive feasibilities of instruments that fold an ensemble adequately; 2) even distribution of thematic material between them; 3) avoidances are in parties of those registers, that assist the removal of tone quality (subzero and high registers are used with the aim of differentiation of lines); 4) uses of register compactness of sounding; 5) use of short dialogues-transmissions of equivalent melodious phrases; 6) association of pair of instruments is in the "duet of consent" in a consonance interval (third, sixth).
\end{abstract}

Citation: Ірина Смірнова. (2019) Pryntsypy Vzaiemodii Instrumentiv v Zmishanomu Ansambli na Prykladi Trio dlia Skrypky, Valtorny ta Fortepiano or. 40 Y. Bramsa. World Science. 6(46), Vol.2. doi: 10.31435/rsglobal_ws/30062019/6564

Copyright: (C) 2019 Ірина Смірнова. This is an open-access article distributed under the terms of the Creative Commons Attribution License (CC BY). The use, distribution or reproduction in other forums is permitted, provided the original author(s) or licensor are credited and that the original publication in this journal is cited, in accordance with accepted academic practice. No use, distribution or reproduction is permitted which does not comply with these terms.

Вступ. Поступова еволюція гуманістичних, антропоцентричних та індивідуалістичних тенденцій у європейській культурі від доби Відродження привела до суттєвих перетворень у стильових та жанрових системах усіх видів мистецтва доби Нового часу, зокрема в мистецтві музичному. Намагання виявити свою індивідуальність, неповторну сутність через вільне музикування, гру як незацікавлену діяльність сприяли формуванню таких жанрів, образносемантичне наповнення й композиційно-драматургічні особливості яких створювали можливість розкриття та реалізації творчих потенцій особистості. До таких належать практично всі інструментальні жанри, що склалися в барокову добу: concerto grosso, бароковий сольний концерт, сольна й оркестрова сюїта, барокова соната у двох різновидах. Особливе значення для виявлення індивідуально-особистісних інтенцій у контексті секулярних процесів, що охопили європейську культуру Нового часу, відіграли сольні та ансамблеві жанри. Не випадково їх роль не зменшується і в музиці класицистичної доби, і в епоху романтизму. А в XX столітті камерноансамблева музика переживає нове піднесення, спричинене, безумовно, й власне музичними чинниками, зокрема корінним зламом в музичній мові на межі XIX-XX століть. Таким чином, аксіологічне наповнення камерно-інструментальної музики, іiі антропоцентрична та гуманістична спрямованість, роблять іiі напрочуд гнучкою та життєздатною в змінюваних стильових, мовних і соціокультурних контекстах. Так, після барокової доби в межах музичного класицизму відбулось становлення і кристалізація нових типів камерно-інструментальних жанрів, що відповідали класицистським жанровим канонам і новій стилістиці. Як відзначає відомий дослідник камерно- 
ансамблевої музики I. І. Польська, «класичний етап становлення ансамблевих жанрів пов'язаний із якісним переходом від одних «правил гри» в музичному виконавстві до інших, від одного «ігрового контексту» до іншого, переходом від вільної імпровізаційності до універсального жанрового канону ...» [1, с. 141]. В цілому ж, на думку автора, «період кінця XVIII - XIX ст. був епохою масового розквіту різноманітних форм музикування - сольного та ансамблевого» $[1$, c. 143]. I. I. Польська також зауважує, що «в епоху романтизму камерний ансамбль стає однією 3 найважливіших змістових моделей особистісного спілкування, а ансамбль як такий своєрідною парадигмою романтичної культури» [2, с. 122].

Велике значення камерно-ансамблеві жанри відіграють у творчості Й. Брамса. Серед численних творів для струнних інструментів, струнних та фортепіано, особливе місце у творчому доробку видатного німецького композитора посідають так звані змішані ансамблі за участю духових. Їх виключне становище пояснюється нечисленністю (Тріо ор. 40, Тріо ор. 114, Квінтет ор. 115), а також причинами створення (перший твір опосередковано пов'язаний зі смертю матері, два інших написані під враженням від гри кларнетиста Р. Мюльфельда).

Специфіка змішаних ансамблів полягає в тому, що вони передбачають об'єднання в спільному ансамблевому музикуванні різнотембрових, часто нерівноправних 3 точки зору технічних та виразних можливостей інструментів, що ставить перед композитором додаткові завдання в плані ансамблевого письма для досягнення узгодженості звучання і рівноправності всіх партій. Адже визначальними особливостями ансамблевого виконавства I. I. Польська називає «рівноправну взаємодію партнерів» та «діалогічний (полілогічний) тип комунікативності» [1, с. 210]. Tріо ор. 40 написано для скрипки, валторни в строї Еs та фортепіано, Тріо ор. 114 - для кларнету, віолончелі та фортепіано, Квінтет ор. 115 - для струнних та кларнету. Якщо кларнет $є$ гнучким i технічним інструментом, який може дорівнюватися струнним за силою звучання, віртуозністю та виразністю, то валторна, попри іiі красивий шляхетний тембр, є менш рухливою і більш громіздкою порівняно зі скрипкою i фортепіано. В цьому смислі завданням дослідження $\epsilon$ аналіз ансамблевого письма на прикладі Tріо ор. 40 для скрипки, валторни та фортепіано.

Результати дослідження. У Тріо ор. 40 досягнення узгодженого звучання i рівноправної взаємодії партій відбувається, перш за все, завдяки рівномірному розподіленню тематизму між партіями і обміну рольовими функціями. Так, перше речення теми головної партії спочатку доручено скрипці та фортепіано, при цьому скрипка звучить у низькому регістрі в межах малої і початку першої октави (матово, приглушено), що нівелює ії яскравість; в другому реченні мелодійну ініціативу перехоплює валторна у тій же висотній позиції. Скрипка при цьому змінює ансамблеву функцію: у ритмічній комплементарності з валторною ій доручаються формули акомпанементу подвійними нотами, якими вона ніби обгортає валторну, яка звучить всередині. Фортепіано виконує функцію акомпанементу в акордовій фактурі, гармонійно підтримуючи дві інші партії. Втретє доспівує мелодію теми головної партії одна валторна зі здвигом на терцію угору порівняно із першими двома проведеннями. Таким чином вибудовується темброва симетрія через рівноправне розподілення тематизму: скрипка + фортепіано $\rightarrow$ скрипка + валторна + фортепіано $\rightarrow$ валторна + фортепіано. Подальший розвиток головної партії в ансамблевому плані побудований на діалозі - передачі коротких рівноправних мелодійних фраз від скрипки до валторни на фоні фігураційного руху в партії фортепіано. Обмін короткими репліками призводить до узгодженого моноритмічного звучання двох інструментів у консонуючий інтервал (терція або секста), при цьому теситурно вони обмінюються позиціями: верхню займає або скрипка, або валторна. Зі здвигом по горизонталі по відношенню до скрипки та валторни підключається фортепіано 3 цим самим матеріалом в октавному викладенні мелодії, при цьому октави звуковисотно окружають дві інші партії, що надає звучанню злитності, компактності, а в ансамблевому плані - відчуття дружньої узгодженості, підтримки, задушевного спілкування, що підсилюється ліричним тематизмом. В репризному проведенні теми валторна остаточно посідає теситурно вищу позицію, партія скрипки згортається до звука $\mathrm{b}$ малої октави, від якого розгорталась ії мелодійна ліній на початку. В партії фортепіано присутні октавні ходи, заповнені акордовими звуками, які слугують своєрідним звуковим каркасом, фонічно огортаючи скрипку та валторну, тим самим скріплюючи, об'єднуючи їх у ансамблеву цілісність. Знов три партії звучать спільно в діалогічному просторі дружнього ліричного спілкування. 
В темі побічної партії ініціативу перехоплює скрипка і фортепіано, адже схвильована тема, що побудована на зціпленні секундових і терцових інтонаційних ходів у висхідному i низхідному русі, якнайкраще підходить тембру струнно-смичкового інструменту, який здатний передати інтонації мовлення. Уподібнення до інтонацій живого людського мовлення підсилюється і ритмічною організацією мелодійної лінії: Й. Брамс змінює розмір $32 / 4$ в головній партії на 9/8 в побічній, мелодійні фрази починає на слабкій долі (шоста вісімка), злиговуючи іiі з наступною долею. Початок мелодії переривається паузами. Фортепіано підтримає скрипку пульсуючим акомпанементом бас + дві вісімки. Нестійкість теми підкреслюе тонально-гармонійна логіка: при знаках g-moll, які композитор виставляє на початку розділу побічної партії, тональною опорою в першому такті є до мінор, соль мінор 3'являється лише на третій долі цього такту, а далі пануючими стають акорди субдомінанти і верхньої та нижньої медіанти. Соль в басу репрезентує секстакорд VI ступеню, а соль мінор з'являється на слабкій долі такту у вигляді секстакорду. За таких умов валторна не виключається із тематичного і ансамблевого процесу. Композитор доручає ій короткі мелодійні фрази (зерно теми, побудоване на зціпленні секунди та терції) - своєрідні зітхання, які подані більш крупними тривалостями, ніж у скрипки. Вони звучать нижче за струнний інструмент, проте регістрово від нього не віддаляються, завдяки чому знов досягається узгоджене компактне звучання. Важливість ролі валторни в побічній партії підтверджує друге проведення теми в експозиції і проведення в репризі. В першому випадку мелодію починає коротке зітхання валторни, який підхоплює скрипка: валторна неначе дає імпульс, який договорює іiі партнер, розподіл мелодійної лінії між двома інструментами створює відчуття єдності, своєрідного діалогу порозуміння. В репризі партія валторн одразу ж підключається до викладення теми спочатку в діалозі на коротких зітханнях, потім гнучко відтворюючи непростий ритм мелодійної лінії скрипки. Композитор лише в деяких моментах спрощує його, подовжуючи звуки. Тим самим долається громіздкість інструменту, технічно і виразно він дорівнюється скрипці. В експозиції тема втретє передається фортепіано, скрипка та валторна об'єднуються у спільному звучанні у консонуючі інтервали (терція, секста, октава), а партія фортепіано знов звуковисотно-фонічно огортає їх у м'якому фігуративному русі. В репризі спільно-узгоджене звучання настає після першого проведення, в плані ансамблевого письма вона вирішена подібно до експозиційного фрагменту.

Друга частина Тріо ор. 40 - скерцо - демонструє абсолютне рівноправ'я ансамблевих партнерів, яке досягається великою мірою завдяки типу тематизму. Традиційно скерцо в цілому написане в складній трьохчастинній репризній формі da саро, в крайніх розділах якої музичний процес замикається у коло також завдяки трьохчастинній репризній формі. Драматургія кола, характерна для скерцо, диктує принципи формотворення і на менших масштабних рівнях форми, що виявляється у пануванні трьохчастинних структур. Форма, що вибудовується, вкладається в таку схему: А $(A(\boldsymbol{a b a l})-B-A 1)-\mathbf{B}-\mathbf{A 1}$ (відповідно, 3 повтором усіх структурних складових без скорочень). Пружно-моторна тема скерцо є «зручною» для всіх трьох інструментів. Вона «сконструйована» 3 декількох елементів. Перший елемент (розділ $\boldsymbol{a}$ ) звучить в партії фортепіано, він неширокого діапазону, побудований на русі по діатонічним звукам Es-dur, з опорою на звуки тризвука. Його лапідарність, токатність, сухість підкреслені октавним (в дві октави) викладенням стаккато. 3 другим тематичним елементом контрапунктом до першого нашаровуються скрипка та валторна (переважно у моноритмічному звучанні). Цей елемент містить повтори звуків та кличні інтонації - родові перш за все для валторни, що дозволяє органічно вплітати цей інструмент в ансамбль. Фортепіано компенсує сухість моноритмічної подвоєної в консонуючі інтервали лінії скрипки та валторни появою акордів в партії правої руки, тоді як ліва продовжує грати октавами. Швидкий темп Allegro не становить перешкоди для узгодженості та гнучкої рухливості звучання. Середній розділ в побудований на діалогічному співставленні кличних повторень звуків у скрипки та валторни та стакатних ходів в партії лівої руки у фортепіано. Гнучкість діалогу досягається зняттям акордової фактури у фортепіано i, власне, сплетінням трьох ліній, дві з яких об’єднуються у моноритмічному звучанні. Далі пом'якшення викладення підкреслюється штрихом лигато та довгими нотами у струнного та духового інструментів. Репризне проведення теми) розділ $\boldsymbol{a} 1$ позначене передачею першого тематичного елемента від фортепіано (в експозиційному проведенні) до скрипки та валторни, при чому валторна займає більш високу теситурну позицію по відношенню до 
скрипки: вони грають у сексту. Фортепіано підтримує партнерів делікатними октавними ходами стаккато, розірваними паузами. Середній розділ крайньої частини $B$ містить і октавний тематичний елемент розділу А, і новий матеріал, що продовжує лінію м'якого діалогу розділу в. Тут знов об'єднуються скрипка та валторна у пару, що співставляється 3 фортепіанними октавними ходами по звукам тризвуків, штрих лигато. Реприза $A 1$ має синтетичний характер і не $є$ буквальним повторенням $A$. Вона починається діалогом середнього розділу в основній тональності Es-dur, потім вступає основна тема $A$ немов би 3 другого проведення (у сукупності першого та другого елементів) у всіх трьох інструментів. Далі за планом - діалогічний фрагмент в зі змінами в розташуванні скрипки та валторн відносно один одного. Так, в експозиційному проведенні скрипка грає секунду - es-f у другій октаві, валторна грає $f$ у першій, у репризі у скрипки звучить октава від $b$ першої октави, тоді як валторна грає звук $a s$ першої октави: секунда опиняється внизу. В будь якому разі інструменти не віддаляються на велику відстань, що надає звучанню ансамблевої узгодженості і компактності, зближує тембри скрипки та валторни. Фортепіано, у свою чергу, і об'єднується зі скрипкою і валторною завдяки єдності тематичного матеріалу, гнучким передачам мелодійних фраз, що створює полілог учасників ансамблю, i протиставляється парі інструментів через регістрову віддаленість. Справа в тому, що партія фортепіано містить два фактурних елементи: октавні ходи стаккато, верхній голос яких регістрово і тематично наближений до партій скрипки та валторни, нижній же заповнює середній регістр. Другий елемент - це октавна педаль в самому низькому регістрі, яка стає гармонійною і фонічною основою ансамблю і водночас віддаляє фортепіано від інших партій.

Середній розділ Molto meno Allegro складної трьохчастинної форми скерцо контрастує крайнім розділам більш приглушеним - камерним - звучанням. Композитор тут використовує ансамблевий прийом, який ми зустрічали в I частині. Для досягнення ефекту приглушеного неяскравого звучання скрипка «опускається» в низький регістр, а валторна розміщується на терцію або сексту вище за скрипку. Фортепіано огортає їх октавними ходами. Партія правої руки фортепіано, скрипка та валторна об'єднуються у компактному звучанні з точки зору регістрового розташування, що слугує на користь їх тембрової близькості.

III частина Adagio mesto $є$ ліричним центром циклу. Скорботний характер музики створює яскравий контраст моторному скерцо і життєрадісному фіналу. Тема побудована на комплексі інтонацій, які вироблені практикою оперного lamento, закріпилися в сфері ліричного інструментального висловлювання. Це оспівування зменшеної кварти, секундові інтонації «зітхання», секстові ходи, зціплення секунд у висхідному та низхідному русі, в цілому м'який малюнок мелодії, що підкреслюється розміром 6/8. Характерно, що після невеликого чотиритактового вступу на секундовому колиханні, тему викладають всі три інструменти, причому скрипка веде головну мелодійну лінію, валторна - ii моноритмічний варіант, фортепіано - контрапункт, який нагадує мелодію ритмічно. Це призводить до, по-перше, рівноправності партій, по-друге, - їх тембрового об’єднання, по-третє - відчуття скорботного «ансамблю згоди», який відсилає до оперної та кантатно-ораторіальної музики. Вертикальна узгодженість перших чотирьох тактів викладення теми переростає у полілог партій, який не порушує єдності, адже він побудований на дуеті фортепіано та скрипки (друге речення), який підтримує валторна короткими фразами. Велика роль імітаційного викладення в подальшому музичному процесі підтверджує рівноправність партій. Майже весь середній розділ є цариною діалогу скрипки та валторни, що побудований на імітаційному проведенні мелодійних фраз на фоні повнозвучних акордів, а згодом фігурацій в партії фортепіано. В репризі «скорботний дует» при підтримці фортепіано повертається. Досягаючи найвищої кульмінаційної точки, композитор зберігає компактність розташування скрипки та валторни: вони як верхньому для валторни, так і в нижньому для скрипки регістрі не віддаляються одна від одної. Натомість об’єм і повнота звучання на кульмінації досягається за рахунок широких акордів у фортепіано, які охоплюють великий діапазон, рухаючись від нижнього до верхнього регістрів.

Життерадісний моторний фінал в швидкому темпі і в розмірі 6/8 різко контрастує попередній частині, перекидаючи арку до скерцо. Мелодія теми в русі вісімками, як і в скерцо, «сконструйована» зручно для всіх інструментів, що входять до складу ансамблю. Валторна, яка приєднується до скрипки у другому реченні, не дограє мелодію лише через технічний брак повітря, знов приєднуючись до партнера на довгих нотах. Включені в мелодію репетиційні повтори звуків 
адекватно відповідають технічним можливостям валторни, зокрема, прийому подвійного язика, а темі побічної партії - потрійного язика. В цілому в фіналі діють ті принципи співвідношення інструментів, які ми зустрічали в попередніх частинах. Це регістрова близькість скрипки та валторни, досягнення повноти об'єму звучання за рахунок партії фортепіано, яка охоплює різні регістри, передачі рівноправних мелодійних ліній від скрипки до валторни за підтримкою фортепіано, об'єднання струнного та духового інструментів у консонуючі інтервали. Показово, що в фіналі композитор «дозволяє» скрипці вирватись в яскравий верхній регістр, ненадовго «відірватись» від валторни, що створює блискучий, життєрадісний образ.

Висновки. В результаті аналізу специфіки взаємодії нерівнозначних з технічної та виразної точок зору інструментів (скрипки, валторни in Es, фортепіано) в Тріо op. 40, ми дійшли висновку, що Й. Брамс досягає узгодженого ансамблевого звучання завдяки комплексу таких прийомів: 1) створення тематизму, який адекватно відповідає технічним та виразним можливостям інструментів, що складають ансамбль; 2) рівномірному розподілу тематичного матеріалу між ними; 3) уникнення в партіях тих регістрів, які сприяють віддаленню тембрів (низькі та високі регістри використовуються 3 метою диференціації ліній), в результаті валторна грає переважно у середньому та високому регістрах, рідко виходячи в низький, а у скрипки виявляється часто задіяним низький регістр; 4) використання регістрової компактності звучання; 5) використання коротких діалогів-передач рівноцінних мелодійних фраз; 6) об'єднання пари інструментів у «дует згоди» в консонуючий інтервал (терція, секста, децима).

\section{REFERENCES}

1. Польская И. И. Камерный ансамбль: История, теория, эстетика: Монография. Харьков: ХГАК, 2001. 396.

2. Польська I. І. Історичні модуси камерного ансамблю в дзеркалі музичної герменевтики. Культура Украӥни. Харків, 2017. 57. 119 - 128. 